\title{
KONSELING DAN PLURALISME AGAMA DALAM MEDITASI DI VIHARA KARANGDJATI YOGYAKARTA
}

\author{
Bigmen Pangestu \\ Mahasiswa Pacasarjana UIN Sunan Kalijaga Yogyakarta \\ bigmenasta@gmail.com
}

\begin{abstract}
Using Meditation as a medium in Counseling makes the counseling process fresher and more interesting. Because one of the challenges a counselor must face in the interfaith Guidance and Counseling process is how to respond to religious differences. Religious differences should not be an obstacle in the counseling process. Understanding religious pluralism is a need for a counselor in the counseling process in a pluralistic society. Religious pluralism is based on the assumption that all existing religions are equally valid paths to God. The practice of meditation at Vihara Karangdjati is a clear example of the attitude of pluralism. There, people from different religious backgrounds gather and socialize in a peaceful and understanding manner between religions. Counseling and religious pluralism in meditation at Vihara Karangdjati is the provision of counseling services to meditation participants of different beliefs or religions with a meditation guide as a counselor. The awareness of the guides and meditation participants on religious pluralism makes the process of meditation as interfaith counseling run well.
\end{abstract}

\section{Keywords: Counseling; Pluralism; meditation; Vihara} Karangdjati 


\section{A. Pendahuluan}

Praktek meditasi telah menyebar ke seluruh lapisan masyarakat. Tujuan melakukan meditasi beragam. Dalam buku Latihan Meditasi Untuk Psikoterapi, M.A. Subandi mengutip pernyataan Wals, bahwa ada dua tujuan akhir dari praktek meditasi, yaitu pertama agar seseorang dapat memiliki perkembangan insight yang paling dalam tentang proses mental di dalam dirinya, insight tentang kesadaran, identitas dan realitas; kedua agar seseorang memperoleh perkembangan kesejahteraan psikologis dan kesadaran yang optimal. ${ }^{1}$ Maka tidak ada salahnya ketika memanfaatkan meditasi sebagai media untuk melakukan konseling.

Salah satu komunitas atau kelompok meditasi adalah kegiatan meditasi di Vihara Karangdjati Yogyakarta. Dari lokasi meditasinya saja sudah dapat ditebak bahwa kelompok meditasi ini menggunakan metode meditasi Buddis. Ajaran Buddha, khususnya tentang meditasi, bertujuan untuk kondisi kesehatan mental yang sempurna, kedamaian dan ketenangan. ${ }^{2}$ Kelompok meditasi ini terbuka untuk umum. Artinya tidak membatasi pesertanya terkait agama, suku, dan umur. Semua masyarakat yang ingin meditasi dipersilakan bergabung.

Praktek meditasi di Vihara Karangdjati hadir di tengah kehidupan sosial masyarakat yang tidak terhindarkan dari penuh perbedaan. Sering kali perbedaan itu menjadi sebab terjadinya pertengkaran dan permusuhan antara individu satu dengan yang lain, atau kelompok satu dengan kelompok yang lain sehingga kerap menimbulkan perpecahan dalam hidup bermasyarakat. Semua perbedaan-perbedaan memiliki potensi menjadi sebab perpecahan itu. Salah satunya adalah perbedaan agama.

Setiap daerah memiliki ciri khas budaya maupun agama yang berbeda-beda. Agama adalah suatu bentuk ikatan hidup yang mengandung pengakuan pada suatu sumber yang berbeda dari diri manusia dan yang mempengaruhi perbuatan-perbuatan

1 M.A Subandi, Latihan Meditasi Untuk Psikoterapi (Universitas Gadjah Mada: Unit Publikasi Fakultas Psikologi, t.t.).

2 Hastho Bramantyo, "Meditasi Bhuddis: Sarana Untuk Mencapai Kedamaian dan Pencerahan Batin," Orientasi Baru Vol 24, No. 1, April (2015). 
manusia, sehingga timbul pengakuan akan adanya kewajibankewajiban yang diyakini dan harus dilakukan³. Dapat dipahami bahwa agama memengaruhi cara pandang dan kehidupan seseorang dalam bertingkah laku dengan masyarakat sekitarnya sehingga kepercayaan yang dianut dalam suatu lingkungan masyarakat memiliki keterikatan yang kuat dalam kehidupan seseorang untuk menjalankan kewajiban-kewajiban yang diyakininya. Sedangkan Budaya merupakan sikap, nilai, dan keyakinan dan perilaku yang dimiliki bersama oleh sekelompok orang yang dikomunikasikan dari satu generasi ke generasi berikutnya lewat bahasa atau beberapa sarana komunikasi yang lain. 4 Adanya perbedaan agama dan budaya merupakan realitas hidup yang tidak dapat di hindari. Hal inilah yang menyebabkan adanya perbedaan pola kehidupan ataupun pola berpikir masyarakat setempat, sehingga muncullah pemahaman yang berbeda antar daerah.

Perbedaan agama di masyarakat adalah suatu hal yang tidak perlu dikhawatirkan selama setiap individu di dalam kehidupan sosial masyarakat itu memiliki toleransi antar umat beragama untuk menjaga kerukunan sosial. Rasa saling menyayangi dan menghormati antar umat beragama akan menciptakan sejuknya kedamaian dalam kehidupan sehari-hari di masyarakat.

Agama bukanlah pagar penghalang antara individu satu dengan individu yang lain untuk melakukan interaksi sosial. Termasuk interaksi antara konselor dengan konseli dalam proses konseling. Kepekaan komunikasi dalam proses konseling menjadi tantangan seorang konselor ketika menemui klien yang berbeda agama. Proses konseling tidak mempermasalahkan latar belakang agama konselor dan agama konseli. Namun tentu ada pengaruhnya terhadap proses konseling. Oleh karena itu konselor pun dalam proses konseling lintas agama perlu memahami agama yang dianut konseli agar proses konseling berjalan dengan lancar.

${ }^{3}$ Jalaluddin, Psikologi Agama (Jakarta: PT Raja Grafindo Persada, 2010). Hal 30.

4 David Matsumoto, Pengantas Psikologi Lintas Budaya, Trjmh. Anindito Aditomo (Yogyakarta: Pustaka Pelajar, 2008). Hal. 18 
Pemanfaatan meditasi sebagai media merupakan kesegaran dalam proses konseling. Meditasi bukanlah ritual dari agama tertentu, sehingga semua orang dari latar belakang agama apa saja dapat melakukan meditasi. Vihara Karangdjati merupakan salah satu penyelenggara praktik meditasi di Yogyakarta. Di sana peserta meditasi berasal dari latar belakang agama yang berbedabeda, mereka sebagai konseli dapat membentuk sebuah kelompok konseling atau bisa berkonsultasi mengenai berbagai permasalahan kepada pemandu meditasi sebagai konselor.

\section{B. Pluralisme Agama}

Istilah pluralisme pada awalnya adalah terminologi filsafat yang berkembang di Barat. Istilah ini lahir dari pernyataan ontologis tentang "yang ada", dalam menjawab pernyataan tersebut kemudian muncul 4 (empat) aliran yaitu: monoisme, dualisme, pluralisme, dan agnotisisme. ${ }^{5}$

Dalam pandangan lainnya, pluralisme memiliki arti bahwa kebenaran tidak hanya datang dari satu sumber, melainkan juga berasal dari sumber lain yang bersifat plural. Di Inggris pluralisme semakin populer pada awal abad ke-20 melalui para tokoh (sebagaimana dikutip oleh Muhyar Fanani) seperti F. Maitland, S. G. Hobson, Harold Laski, R. H. Tawney dan GDH Cole. ${ }^{6}$

Jika perspektif pluralisme ini digunakan untuk melihat fenomena aliran keagamaan, maka lahirlah pandangan bahwa: (1) Kebenaran yang diakui oleh setiap aliran (agama) bersifat nisbi, dengan kata lain tidak ada kebenaran tunggal; (2) kebenaran yang diakui oleh setiap aliran memiliki nilai yang sama dan tidak satupun berada di atas yang lainnya; (3) aliran keagamaan harus diperlakukan sebagai entitas eksistensial mandiri yang menganut pandangan filsafat dan sistem nilai sendiri yang bisa diungkapkan dalam berbagai bentuk dan tradisi. Ini berarti, bahwa setiap aliran keagamaan tidak bisa direduksi dan dipaksa bersatu dengan aliran lainnya, dan tidak

${ }^{5}$ M. Zainuddin, Filsafat Ilmu: Persfektif Pemikiran Islam (Jakarta: Lintas Pustaka, 2006).

${ }^{6}$ Muhyar Fanani, “Mewujudkan Dunia Damai: Studi atas Sejarah Ide Pluralisme Agama dan Nasionalisme di Barat," Jurnal Wacana Hukum Islam, P3M STAIN Salatiga, 2003. 
atupun aliran keagamaan yang bisa meniadakan aliran yang lain. 7

Pluralisme juga bisa diartikan sebagai suatu keadaan di mana eksistensi kelompok dalam sebuah negara atau masyarakat yang memiliki perbedaan, baik dari segi suku, budaya, dan agama. Dalam pengertian yang lebih sederhana, pluralisme adalah suatu keadaan yang beraneka ragam. ${ }^{8}$

Menurut Nurcholish Madjid, ada tiga sikap dialogis agama yang dapat dilihat. Pertama, sikap eksklusif dalam melihat agama lain (agama lain adalah jalan yang salah dan menyesatkan bagi pemeluknya); Kedua sikap inklusif (agama-agama lain adalah bentuk implisit agama yang kita anut dan yakini); Ketiga, sikap pluralis yang dapat terekspresi dalam macam-macam rumusan. Misalnya, agama-agama lain adalah jalan yang samasama sah untuk mencapai kebenaran yang sama. Menurut Nurcholish Madjid, Islam adalah agama inklusif dan merentangkan tafsirannya ke arah yang semakin pluralis. Dalam konteks filsafat Perenial ditegaskan bahwa setiap agama sebenarnya merupakan ekspresi keimanan terhadap Tuhan yang sama. Ibarat roda, pusat roda itu adalah Tuhan, dan jari-jari adalah jalan dari berbagai agama. Nurcholish menambahkan pula, bahwa pluralisme sesungguhnya adalah sebuah sunnatullah yang tidak akan berubah, sehingga juga tidak mungkin untuk dilawan atau diingkari. ${ }^{9}$

Tokoh pluralis lainnya, Budhy Munawar-Rachman menulis sebuah buku dengan judul "Basis Teology Persaudaraan Antar Agama", dalam buku ini dia memaparkan gagasan teologi Pluralis, ia berpendapat bahwa konsep teologi pluralis memberikan legitimasi kebenaran untuk semua agama, bahwa pemeluk agama apapun dapat disebut sebagai "orang yang beriman", dalam arti orang tersebut "percaya dan menaruh kepercayaan kepada Tuhan", Budhy Munawar Rachman

7 M. M. Billah, Pluralitas Agama di Indonesia: Memilih Kerangka Pemahaman atas Keberadaan Aliran Keagamaan dari Perspektif Teologi dan HAM, Makalah (Malang: UIN Malang, 2007).

8 Victoria Neufeldt, Webster's New World College Dictionary (USA: Micmillan, 1996).

9 Nurcholish Madjid, Islam Doktrin dan Peradaban (Jakarta: Paramadina, 1999). 
menyimpulkan bahwa yang diperlukan saat ini dalam penghayatan pluralism antar-agama adalah pandangan bahwa siapa pun yang beriman tanpa harus melihat agamanya apa, adalah sama di hadapan Allah, karena Tuhan kita semua adalah Tuhan yang Maha Satu". ${ }^{10}$

Dalam merespon pandangan tersebut, umat Islam secara umum terbagi ke dalam dua aliran besar;

Pertama, bahwa pluralisme agama merupakan suatu keniscayaan, dia merupakan fitrah manusiawi, dia merupakan sunnatullah, sehingga pluralisme agama tidak dapat dielakkan, bahkan harus diimani dan disosialisasikan kepada seluruh pemeluk agama yang berbeda. Dalam pemaknaan yang pertama inilah, yang dimaksudkan dalam fatwa Majelis Ulama Indonesia (MUI) melalui Surat Keputusan Majelis Ulama Indonesia (MUI), nomor: 7/MUNAS-VII/MUI/II/2005 tentang Sekularisme, Liberalisme, dan Pluralisme Agama. Dalam amar putusan tersebut dinyatakan dengan tegas bahwa paham ini bertentangan dengan ajaran Islam dan haram bagi kaum Muslim untuk mengakui atau memeluk paham semacam itu. ${ }^{11}$

Kedua, pluralitas agama adalah kondisi di mana berbagai agama mewujud (eksis) secara bersamaan dalam suatu negara/masyarakat, pluralisme agama dalam konteks kedua ini adalah sebuah konsep interaksi antar berbagai pemeluk agama yang berbeda, tanpa saling mengganggu keyakinan/aqidah masing-masing, serta tidak pula mencampuradukkan keyakinan agama-agama yang berbeda.

Pluralisme dan pluralitas merupakan dua istilah yang sering digunakan secara bergantian tanpa ada penjelasan apakah kedua kata tersebut memiliki arti sama atau berbeda. Adakalanya pluralisme dan pluralitas diartikan sama, yakni sebuah keadaan yang bersifat plural, jamak atau banyak. Pluralisme sebenarnya bukan hanya sekadar keadaan yang bersifat plural atau sekadar pengakuan bahwa heterogenitas itu

10 Budy Munawar Rachman, Basis Teology Persaudaraan Antar Agama, dalam "Wajah Liberal Islam Indonesia" (Jakarta: Jaringan Islam Liberal, 2007).

11 "Surat Keputusan Majelis Ulama Indonesia (MUI)," nomor /MUNAS-VII MUI II 2005. 
ada dalam realitas. Sejatinya pluralisme merupakan sikap mengakui, menghargai, menghormati, memelihara, mengembangkan dan memperkaya keadaan yang bersifat plural tersebut. Dalam konteks agama-agama, meskipun dengan jalan yang berbeda-beda, menuju kepada satu tujuan yang sama, Yang Absolut, Yang Terakhir, yakni Tuhan. ${ }^{12}$

Dalam perspektif M. Amin Abdullah, pluralisme agama seperti meracik anggur dalam botol yang lama (put a new wine in the old bottle). Botolnya tetap sama, artinya bahwa pluralisme setua usia manusia dan selamanya akan ada. Hanya cara membuat minuman anggur akan bisa selalu berubah, sesuai dengan perkembangan metodologi pembuatan minuman yang ada. ${ }^{13}$ Pluralisme menjadi penting dalam beragama, karena umat dalam suatu agama tidak bisa lagi mengisolasi diri dari berbagai identitas agama yang lain. Pertemuan antar umat beragama mengharuskan untuk saling memahami dan menghormati nilainilai keagamaan satu sama lain. ${ }^{14}$ Sikap terbuka dari setiap umat beragama akan melahirkan perdamaian serta toleransi yang dapat menjadi perisai dari sikap saling menyalahkan. ${ }^{15}$

Menurut Syafii Maarif, sebagai warga dunia setiap orang mesti memahami berbagai ajaran universal yang ada dalam setiap agama. ${ }^{16}$ Senada dengan itu, Ananda K. Coomaraswamy (1877-1947) berpendapat bahwa hubungan baik antar umat beragama tidak akan terjadi bila kebenaran hanya dimonopoli oleh agama tertentu. ${ }^{17}$ Maka dari itu, memahami arti penting dari

12 Madjid, Islam Doktrin dan Peradaban.

13 M. Amin Abdullah, Dinamika Islam Kultural: Pemetaan atas Wacana Islam Kontemporer (Bandung: Mizan, 2000).

14 Mustafa Ruzgar, Islam and Deep Religion Pluralism, dalam David Ray Griffin, ed., Deep Religious Pluralism (Kentucky: John Knox Press, 2005).

15 M. Amin Abdullah, Kebebasan Beragama atau Dialog antar Agama, dalam J.B Banawiratma et al, Hak Asasi Manusia Tantangan Bagi Agama (Yogyakarta: Kanisius, 1999).

16 Ahmad Syafii Maarif, Islam dalam Bingkai Keindonesiaan dan Kemanusiaan: Sebuah Refleksi Sejarah (Bandung: Mizan, 2009).

17 Ananda K. Coomaraswamy, Paths that Lead to the Same Summit, dalam Martin Lings dan Clinton Minnar, eds.The Underlying Religion: An Introduction to the Perennial Philosophy (Indiana: World Wisdom, 2007). 
eksistenti setiap agama merupakan pondasi filosofis yang mesti dibangun sebelum berbicara mengenai berbagai agenda kemanusiaan. Hal tersebut bahkan mendorong munculnya suatu kesadaran baru dalam beragama seperti: to be religious is to be interreligious (beragama berarti membangun hubungan dengan penganut agama lain). ${ }^{18}$ dengan demikian pluralisme agama tidak bisa dipahami hanya dengan mengatakan bahwa masyarakat majemuk yang terdiri dari berbagai suku dan agama. Hal itu justru hanya akan menggambarkan fragmentasi bukan kemajemukan. Pluralisme agama juga tidak bisa dipahami hanya sekadar sebagai kebaikan negatif (negative good), hanya dilihat dari kegunaannya untuk menyingkirkan fanatissisme (to keep fanaticsm at bay), pluralisme agama mesti dipahami sebagai pertalian sejati kebhinekaan dalam ikatan-ikatan keadaban (genuine engagement of diversities within the bonds of civility). ${ }^{19}$ Bahkan Amir Hussain berpendapat bahwa pluralisme agama adalah suatu keharusan bagi keselamatan umat manusia. ${ }^{20}$

Pluralisme agama tidak bisa disamakan dengan istilah 'toleransi' atau 'saling menghormati' antar umat agama. Sebagai suatu paham (isme), pluralisme agama telah menjadi pembahasan panjang oleh para akademisi atau para peneliti dalam studi agama-agama.

Pluralisme agama berdasar pada asumsi bahwa semua agama yang ada adalah jalan yang sama-sama sah menuju Tuhan. Jadi, menurut paham ini, semua agama adalah jalan berbeda-beda untuk menuju Tuhan yang sama. Atau, bahwa agama adalah persepsi manusia yang relatif terhadap Tuhan yang mutlak, sehingga - karena kerelativannya - maka setiap pemeluk agama tidak boleh mengklaim bahwa agamanya lebih baik dan benar dari agama lain. ${ }^{21}$

18 Budly Munawwar Rahman, Islam Pluralis: Wacana Kesetaraan Kaum Beriman (Jakarta: Paramadina, 2001), hal. 14.

${ }_{19}$ Munawwar Rahman, 31.

20 Amir Hussain, Muslims, Pluralism, and Interfaith Dialogue, dalam Omid Safi, ed.Progressive Muslim: On Justice, Gender and Pluralism (Oxford: One World, 2004).

21 Charles Kimball, When Relegion Become Evil (New York: HarperSanFrascisco, 2002). 
Paham ini telah menyerang semua agama, klaim-klaim kebenaran mutlak atas masing-masing agama diruntuhkan, karena berbagai alasan dan sebab. Salah satu teolog Kristen yang terkenal sebagai pengusung paham ini, Ernest Troeltsch, mengemukakan tiga sikap terhadap agama-agama, yaitu (1) semua agama adalah relatif. (2) Semua agama, secara esensial adalah sama. (3) Semua agama memiliki asal-usul psikologi yang umum. ${ }^{22}$

\section{Konseling dalam Konteks Pluralisme Agama}

Konseling dalam konteks pluralisme agama adalah pemberian layanan konseling terhadap konseli yang berbeda kepercayaan atau agama dengan konselor. Bimbingan dan konseling lintas agama, sebenarnya merupakan rumusan dan implementasi layanan bimbingan konseling itu sendiri yang bertujuan untuk memfasilitasi klien agar bisa mengembangkan potensinya secara maksimal serta mencapai tugas perkembangan yang menyangkut aspek fisik, emosi, intelektual, sosial dan moral spiritual. Kegiatan konseling pada hakikatnya dapat dilakukan dimana-mana, baik secara resmi sesuai dengan jabatannya dan lembaga atau badan yang menyelenggarakan, maupun secara tidak resmi.

Istilah konseling berasal dari bahasa inggris yaitu counseling. Sedangkan kata counseling dari kata to counsel yang artinya memberikan nasehat atau memberikan nasehat atau anjuran kepada orang lain secara face to face (berhadapan muka satu sama lain) dan juga bisa diartikan advice, yang artinya nasehat atau petuah. Menurut Prayitno \& Amti konseling adalah proses pemberian bantuan yang dilakukan melalui wawancara konsleing oleh seorang ahli (disebut konselor) kepada individu yang sedang mengalami suatu masalah (klien), yang bermuara pada teratasinya masalah yang dihadapi oleh klien. Lebih lanjut Shrezer \& Stone menyatakan bahwa konseling adalah proses interaksi yang memudahkan pengertian diri dan lingkungan serta hasil-hasil pembentukan dan atau klarifikasi tujuan-tujuan

22 Alister E. Mcgrath, Christian Theology: an Introduction (Oxford: Blackwell Publisher, 1994); Daniel B. Clendenim, Many Gods Many Lord: Christianity Encounters World Relegions (Michigan: Baker Book, 1995). 
dan nilai-nilai yang berguna bagi tingkah laku yang akan datang. ${ }^{23}$

Berikutnya adalah kata Agama, menurut Harun Nasution agama berasal dari kata al-adin, religi, relegere, religale) dan agama. Al-din (Semit) berarti undang-undang ata hukum. Kemudian dalam bahasa Arab, kata ini mengandung arti menguasai, menundukkan, patuh, utangg, balasan dan kebiasaan. Adapun dari kata Religi (Latin) atau relegere berarti mengumpulkan dan membaca. Secara definitif, menurut Harun Nasution, agama adalah:

1. Pengakuan terhadap adanya hubungan manusia dengan kekuatan gaib yang harus dipatuhi.

2. Pengakuan terhadap adanya kekuatan gaib yang menguasai manusia.

3. Mengikat diri pada suatu bentuk hidup yang mengandung pengakuan pada suatu sumber yang berada diluar diri manusia dan mempengaruhi perbuatan-perbuatan manusia.

4. Kepercayaan pada suatu kekuatan gaib yang menimbulkan cara hidup tertentu.

5. Suatu sistem tingkah laku yang berasal dari kekuatan gaib.

6. Pengakuan terhadap adanya kewajiban-kewajiban yang diyakini bersumber pada suatu kekuatan gaib.

7. Pemujaan terhadap kekuatan gaib yang timbul dari perasaan lemah dan perasaan takut terhadap kekuatan misterius yang terdapat dalam alam sekitar manusia.

8. Ajaran-ajaran yang diwahyukan Tuhan kepada manusia melalui seorang Rasul. ${ }^{24}$

Agama menuntun umat manusia menuju kesempurnaan dan kesejahteraan hidup, tetapi agama juga mempunyai daya ledak yang dapat memicu munculnya konflik. Hal demikian terjadi dikerenakan para pemeluk agama saling bersikukuh terhadap pemahamannya (fanatik) dan tidak mau menolelir pemahaman pemeluk agama lainnya. Di Indonesia ada 6 agama yang resmi diakui: islam, budha, kristen protestan, kristen

${ }^{23}$ Muhamad Rozikan, "Transformasi Dakwah Melelui Konseling Islami," Interdisciplinary Journal of Communication 2 No. 1, Juni (2017).

24 Bambang Syamsul Arifin, Psikologi Agama (Jawa Barat: CV Pustaka Setia, 2015). 
katolik, hindu dan kong hu chu. Masing-masing agama pasti memiliki nilai-nilai khas yang terdapat dalam agama tersebut. Nilai tersebut biasa dikenal dengan istilah nilai partikular. Selain nilai partikular, terdapat juga nilai universal yang artinya setiap agama juga mempunyai nilai-nilai umum yang dipercaya oleh semua agama.

Ada keterkaitan antara agama dan Bimbingan dan Konseling. Peran agama cukup besar dalam hidup seseorang. Ada hal-hal yang perlu diperhatikan berkenaan dengan agama dalam konteks konseling. Di dunia ini jumlah pemeluk agama menempati persentase tinggi, dengan demikian, klien yang ditangani seorang konselor pun berjumlah cukup banyak. Apalagi banyak orang yang mengalami krisis emosi akan cenderung lari pada agama sebagai cara penyelesaian krisis tersebut. Meskipun konselor sendiri tidak lebih religius dibanding kliennya, konselor dituntut agar bisa membantu klien secara maksimal, maka dari itu konselor perlu memahami terlebih dahulu agama yang dianut klien sebelum proses konseling berlangsung, kendati kadang-kadang ada keengganan klien mengikuti proses konseling karena latar belakang agama yang berbeda ia anut dari konselor. Kesadaran konselor pada latar belakang keagamaan klien menjadi hal yang penting karena keberagaman tradisi yang terus berkembang. ${ }^{25}$

Klien yang taat pada agama adalah mereka yang meyakini agamanya melebihi tradisi yang menjadi pegangan masyarakatnya atau keluarganya yang telah mentradisi dari satu generasi ke generasi berikutnya. Tingkat ketaatan ini memiliki dampak pada kehidupan klien, beserta cara pandangnya. Klien yang taat beragama akan memiliki keberanian melihat ke dalam diri mereka sendiri dan menemukan sesuatu yang dapat mereka yakini. Apa yang mereka temukan dalam diri mereka itu bukan hanya sebuah perasaan keterikatan, meskipun mereka bisa saja bukan anggota sebuah kelompok agama terlembaga, dan mereka juga tidak mengikuti kepercayaan-kepercayaan yang mapan. Klien yang terbuka pada agama dan spritual adalah orang yang tidak mempunyai loyalitas secara penuh kepada agama tertentu.

25 Najlatun Naqiyah, "Pendidikan Konselor Religius: Tawaran Pengembanan Bimbingan \& Konseling di Perguruan Tinggi Agama Islam," Al Tahrir Vol 11, No. 2, November (2011). 
Tetapi, selama masa konseling, mereka memperlihatkan sikap keterbukaan pada dimensi agama dan spritual sebagai sesuatu yang relevan dengan permasalahan mereka.

Sedangkan klien yang memiliki keyakinan agama yang dangkal adalah mereka memperlihatkan rasa keberagamaan hanya di kulit luarnya saja, tetapi tidak memiliki ikatan emosi yang tinggi dengan agamanya. Pada klien seperti itu agama tidak terlalu memengaruhi dalam proses konseling, karena agama dianggap sebagai sesuatu yang tidak terlalu penting dalam hidupnya. ${ }^{26}$

Dalam konseling lintas agama, konselor tidak bisa memaksakan nilai-nilai keagamaan mereka kepada diri klien. Seorang konselor harus menghormati nilai-nilai keagamaan klien mereka. Baik konselor maupun klien, keduanya mesti menyepakati adanya zona toleransi. Hal ini untuk menghindari terjadinya hambatan selama proses konseling.

\section{Meditasi sebagai Konseling di Vihara Karangdjati Yogyakarta}

Meditasi di Vihara Karangdjati menggunakan metode meditasi Buddhis. Meditasi Buddhis adalah meditasi ajaran Buddha yang terdiri dari dua jenis meditasi. Pertama, konsentrasi (samatha atau samadhi), yaitu pemusatan atau penyatuan pikiran. Samadhi atau konsentrasi berfungsi untuk menenangkan pikiran. Ketenangan dicapai dengan memusatkan pikiran pada suatu objek. Kedua, pandangan terang (vipassana). Meditasi ini menekankan pada renungan terhadap empat hal yaitu, tubuh, perasaan dan sensasi-sensasi, pikiran, moral dan intelektual. Hal yang essensial dalam meditasi ini adalah kesadaran yang kuat dan pengamatan yang tajam dan jernih. ${ }^{27}$

Meditasi di Vihara Karangdjati tidak pernah kurang dari dua puluh peserta yang hadir dengan latar belakang agama yang berbeda-beda. Mereka yang beragama non-Buddhis tentu menyadari bahwa meditasi yang mereka terapkan adalah meditasi ajaran Buddha atau meditasi Buddhis. Tidak adanya

26 Naqiyah.

27 Bramantyo, "Meditasi Bhuddis: Sarana Untuk Mencapai Kedamaian dan Pencerahan Batin." Hal 18. 
doktrin agama salah satu yang menyebabkan mereka tertarik mengikuti meditasi Buddhis di Vihara Karangdjati.

Dalam prakteknya, kegiatan meditasi di Vihara Karangdjati ini pesertanya begitu plural. Situasi yang plural ini tidak menjadi masalah dalam hubungan sosial antar peserta, namun malah sebaliknya, situasi seperti ini membangun pluralisme dalam komunitas meditasi di Vihara Karangdjati ini. Pluralisme dan pluralitas merupakan dua istilah yang sering digunakan secara bergantian tanpa ada penjelasan apakah kedua kata tersebut memiliki arti sama atau berbeda. Adakalanya pluralisme dan pluralitas diartikan sama, yakni sebuah keadaan yang bersifat plural, jamak atau banyak. Pluralisme sebenarnya bukan hanya sekadar keadaan yang bersifat plural atau sekadar pengakuan bahwa heterogenitas itu ada dalam realitas. Sejatinya pluralisme merupakan sikap mengakui, menghargai, menghormati, memelihara, mengembangkan dan memperkaya keadaan yang bersifat plural tersebut. Dalam konteks agama-agama, meskipun dengan jalan yang berbeda-beda, menuju kepada satu tujuan yang sama, Yang Absolut, Yang Terakhir, yakni Tuhan..$^{28}$

Pelaksanaan meditasi di Vihara Karangdjati rutin setiap jumat malam. Pemandu meditasi sebagai konselor memberi arahan kepada peserta meditasi untuk duduk bersila di tikar yang digelar di lantai Vihara. Proses meditasi kurang lebih selama 30 menit. Para peserta di sini sebagai konseli menumpahkan semua pikiran dan permasalahan ke dalam meditasi dengan bimbingan pemandu meditasi.

Praktek meditasi yang teratur akan mengubah individu menjadi lebih tenang. Individu akan mereaksi gangguangangguan emosi dengan cara yang tidak melukai baik bagi dirinya sendiri maupun orang lain. Meditasi menenangkan pikiran dan membawa individu pada pengertian yang jernih, diman individu merasa terhubung dengan setiap orang dan segala sesuatu. Meditasi merupakan suatu proses perjalanan meniti ke dalam diri sendiri. ${ }^{29}$

28 Umi Sumbulah, "Pluralisme dan Kerukunan Umat Beragama Perspektif Elite Agama di Kota Malang," Jurnal of Sosial Science and Relegion volume 22 No. 01. June (2015).

29 Adya Baskara, Helly P. Soetjipto, dan Nuryati Atamimi, “Kecerdasan Emosi Ditinjau Dari Keikutsertaan Dalam Program 
Selepas proses meditasi, semua peserta termasuk pemandu duduk melingkar. Diskusi bebas atau bimbingan konseling kelompok dipimpin oleh pemandu meditasi selaku konselor. Segala permasalahan, pengalaman meditasi, pengalaman seharihari, atau sekadar perkenalan diri dibebaskan tercurah dalam diskusi atau bimbingan konseling kelompok itu. Semua peserta meditasi yang berlatar belakang agama berbeda-beda bebas saling menanggapi setiap pengalaman atau permasalahan yang disampaikan oleh peserta meditasi lain. Diskusi atau bimbingan konseling kelompok ini dibatasi waktu selama 30 menit saja. Tapi setelah itu, semua peserta meditasi diperbolehkan untuk membentuk kelompok-kelompok diskusi kecil sampai larut malam.

\section{E. Kesimpulan}

Praktek meditasi di Vihara Karangdjati Yogyakarta tidak terlepas dari unsur konseling dan pluralisme agama. Pemandu meditasi sebagai konselor dan peserta meditasi sebagai konseli. Di sana, proses Konseling dibalut dengan meditasi tanpa doktrin dari agama tertentu. Karena para peserta meditasi sebagai konseli berasal dari latar belakang agama yang berbeda-beda, terbangunlah sikap pluralisme dalam setiap individu dalam kondisi sosial yang plural dalam beragama.

Dalam proses bimbingan dan konseling, unsur agama adalah hal yang melekat dan tidak bisa dipisahkan dari pribadi konselor dan klien. Jadi, ketika seorang konselor dapat memahami apa itu pluralisme agama maka konselor akan memiliki sikap hormat pada keyakinan agama yang dianut kliennya, dan perbedaan agama tidak akan menjadi penghambat dalam proses konseling lintas agama.

Meditasi," Jurnal Psikologi 35, no. 2 (17 November 2015): 101 - 115, https://doi.org/10.22146/jpsi.7947. 


\section{Daftar Pustaka}

Abdullah, M. Amin. Dinamika Islam Kultural: Pemetaan atas Wacana Islam Kontemporer. Bandung: Mizan, 2000.

- - - Kebebasan Beragama atau Dialog antar Agama. Dalam J.B Banawiratma et al, Hak Asasi Manusia Tantangan Bagi Agama. Yogyakarta: Kanisius, 1999.

B. Clendenim, Daniel. Many Gods Many Lord: Christianity Encounters World Relegions. Michigan: Baker Book, 1995.

Baskara, Adya, Helly P. Soetjipto, dan Nuryati Atamimi. "Kecerdasan Emosi Ditinjau Dari Keikutsertaan Dalam Program Meditasi." Jurnal Psikologi 35, no. 2 (17 November 2015): 101 - 115. https://doi.org/10.22146/jpsi.7947.

Bramantyo, Hastho. "Meditasi Bhuddis: Sarana Untuk Mencapai Kedamaian dan Pencerahan Batin." Orientasi Baru Vol 24, No. 1, April (2015).

Coomaraswamy, Ananda K. Paths that Lead to the Same Summit. Dalam Martin Lings dan Clinton Minnar, eds.The Underlying Religion: An Introduction to the Perennial Philosophy. Indiana: World Wisdom, 2007.

E. Mcgrath, Alister. Christian Theology: an Introduction. Oxford: Blackwell Publisher, 1994.

Fanani, Muhyar. "Mewujudkan Dunia Damai: Studi atas Sejarah Ide Pluralisme Agama dan Nasionalisme di Barat." Jurnal Wacana Hukum Islam, P3M STAIN Salatiga, 2003.

Hussain, Amir. Muslims, Pluralism, and Interfaith Dialogue. Dalam Omid Safi, ed.Progressive Muslim: On Justice, Gender and Pluralism. Oxford: One World, 2004.

Jalaluddin. Psikologi Agama. Jakarta: PT Raja Grafindo Persada, 2010.

Kimball, Charles. When Relegion Become Evil. New York: HarperSanFrascisco, 2002. 
M. Billah, M. Pluralitas Agama di Indonesia: Memilih Kerangka Pemahaman atas Keberadaan Aliran Keagamaan dari Perspektif Teologi dan HAM. Makalah. Malang: UIN Malang, 2007.

Madjid, Nurcholish. Islam Doktrin dan Peradaban. Jakarta: Paramadina, 1999.

Matsumoto, David. Pengantas Psikologi Lintas Budaya, Trjmh. Anindito Aditomo. Yogyakarta: Pustaka Pelajar, 2008.

Munawar Rachman, Budy. Basis Teology Persaudaraan Antar Agama. Dalam "Wajah Liberal Islam Indonesia". Jakarta: Jaringan Islam Liberal, 2007.

Munawwar Rahman, Budly. Islam Pluralis: Wacana Kesetaraan Kaum Beriman. Jakarta: Paramadina, 2001.

Naqiyah, Najlatun. "Pendidikan Konselor Religius: Tawaran Pengembanan Bimbingan \& Konseling di Perguruan Tinggi Agama Islam." Al Tahrir Vol 11, No. 2, November (2011).

Neufeldt, Victoria. Webster's New World College Dictionary. USA: Micmillan, 1996.

Rozikan, Muhamad. "Transformasi Dakwah Melelui Konseling Islami." Interdisciplinary Journal of Communication 2 No. 1, Juni (2017).

Ruzgar, Mustafa. Islam and Deep Religion Pluralism, dalam David Ray Griffin, ed., Deep Religious Pluralism. Kentucky: John Knox Press, 2005.

Subandi, M.A. Latihan Meditasi Untuk Psikoterapi. Universitas Gadjah Mada: Unit Publikasi Fakultas Psikologi, t.t.

Sumbulah, Umi. "Pluralisme dan Kerukunan Umat Beragama Perspektif Elite Agama di Kota Malang." Jurnal of Sosial Science and Relegion volume 22 No. 01. June (2015).

"Surat Keputusan Majelis Ulama Indonesia (MUI)," nomor /MUNAS-VII MUI II 2005.

Syafii Maarif, Ahmad. Islam dalam Bingkai Keindonesiaan dan Kemanusiaan: Sebuah Refleksi Sejarah. Bandung: Mizan, 2009. 
Syamsul Arifin, Bambang. Psikologi Agama. Jawa Barat: CV Pustaka Setia, 2015.

Zainuddin, M. Filsafat Ilmu: Persfektif Pemikiran Islam. Jakarta: Lintas Pustaka, 2006. 